\title{
Traces of AzTeC Cultural Memory in SIXTEENTH-CENTURY SONGS AND CHRONICLES: The Case of Tlacahuepan
}

\begin{abstract}
This article aims to analyze traces of Aztec cultural memory recorded in sixteenthcentury cultural sources of Central Mexico. It is a study of the particular case of an Aztec hero named Tlacahuepan, whose glorious death was commemorated in many songs and chronicles. The texts in question reveal highly symbolic language, as well as clearly established narrative patterns. The study of their discursive tools can cast considerable light on the ideological background that underlies the oral tradition on which these stories have been based. It can also contribute to a better understanding of the methods and strategies employed by the Aztecs to memorize the past and explain the present.
\end{abstract}

KEYWORDS: Aztecs, cultural memory, myth, history, songs (cuicatl)

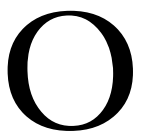

ne of the most admired occupations among the Aztecs, next to warfare, was the composition of songs. The texts of the Nahua cuicatl, which could be translated as "song-dance" and were collected in the sixteenth-century manuscripts of Cantares mexicanos and Romances de los señores de la Nueva España, are examples of relatively direct transmission of the Nahua verbal art. Orality was also one of the channels through which the official state ideology, knowledge of the past, and cultural patterns were transmitted. That is why, as David Damrosch observed, many of these songs, apart from the elaborate aesthetic discourse on values such as friendship, beauty, or war, also reflect the shifting historical contexts in which they were composed or reworked. ${ }^{1}$ In fact, according to Damrosch, being a direct product of the colonial reality and yet deriving from the aesthetics of precolonial oral tradition,

I would like to express my deep gratitude to the anonymous readers for The Americas for their valuable comments that greatly enriched my work. I am also indebted to Julia Madajczak, Agnieszka Brylak, and John F. Schwaller for their constructive suggestions, advice, and support. The results presented in this article are part of the investigation project "The Cultural Topoi in the Pre-Hispanic and Early Colonial Oral Tradition of Central Mexico," financed by the National Science Centre of Poland (UMO-2018/28/C/HS2/00227).

1. David Damrosch, "The Aesthetics of the Conquest: Aztec Poetry before and after Cortés," Representations 33 (1991): 101-120 
many of these "poems" can be interpreted in a bivalent way, frequently making reference to the precontact and postconquest events at the same time. ${ }^{2}$

Undervalued for many years, the texts of cuicatl were rediscovered at the end of the nineteenth century when several of them were translated into English and published by Daniel Brinton. ${ }^{3}$ In the twentieth century, they became an object of more careful study with the works of Leonhard Schultze Jena, and above all, in the translation prepared by Ángel María Garibay Kintana. ${ }^{4}$ The work of Garibay was continued by Miguel León-Portilla and Patrick Johansson. León-Portilla also supervised the publication of the most recent translation of the manuscript of Cantares mexicanos into Spanish. ${ }^{5}$ As for the renderings of these songs into English, both manuscripts have been translated by John Bierhorst, who also prepared the Nahuatl-English Dictionary and Concordance to the Cantares Mexicanos. ${ }^{6}$ Furthermore, the songs in question were the subject of study of such scholars as Richard Haly, David Damrosch, Kay A. Read and Jane Rosenthal, Camilla Townsend, Marie Sautron, Miguel Figueroa Saavedra, Agnieszka Brylak, and Katarzyna Szoblik, among others. ${ }^{7}$

The idea proposed in this article is that the Nahua songs concerned with historical events played an essential role in the process of constructing and transmitting Aztec cultural memory. Jan Assmann defines cultural memory as an institutionalized and

2. Damrosch, "The Aesthetics": 108.

3. Daniel Brinton, Ancient Nahuatl Poetry: Containing the Nahuatl Text of XXVII Ancient Mexican Poems (Philadelphia: Brinton, 1887).

4. Gerdt Kutscher, The Translation of the "Cantares Mexicanos" by Leonbard Schultze Jena (Copenhagen: Munksgaard, 1958); Ángel María Garibay Kintana, Poesía nábuatl I. Romances de los Señores de la Nueva España, Manuscrito de Juan Bautista de Pomar (Mexico City: Universidad Nacional Autónoma de México [hereafter UNAM], 1964); Ángel María Garibay Kintana, Poesía nábuatl II. Cantares mexicanos (Mexico City: UNAM, 1965); Ángel María Garibay Kintana, Poesía nábuatl III. Cantares mexicanos (Mexico City: UNAM, 1968).

5. Miguel León-Portilla, Cantos y crónicas del México Antiguo (Madrid: Historia 16, 1986); Miguel León-Portilla, Quince poetas del mundo Nábuatl (Mexico City: Diana, 1994); Patrick Johansson, La palabra de los aztecas (Mexico City: Trillas, 1993); Patrick Johansson, Miccacuicatl: las exequias de los señores mexicas (Mexico City: Primer Círculo, 2016); Miguel León-Portilla et al., Cantares mexicanos (xico City: UNAM, Fideicomiso Teixidor, 2011).

6. John Bierhorst, Cantares mexicanos. Songs of the Aztecs (Stanford: Stanford University Press, 1985); John Bierhorst, A Nahuatl-English Dictionary of Concordance to the "Cantares mexicanos," Analytic Transcription and Grammatical Notes (Stanford: Stanford University Press, 1985); John Bierhorst, Ballads of the Lords of the New Spain: The Codex "Romances de los Señores de la Nueva España" (Austin: University of Texas Press, 2009).

7. Richard Haly, "The Poetics of the Aztecs," New Scholar 10 (1986): 85-130; Damrosch, "The Aesthetics," 101120; Kay A. Read and Jane Rosenthal, "The Chalcan Woman's Song: Sex as a Political Metaphor in Fifteenth-Century Mexico," The Americas 62:3 (2006): 313-348; Camilla Townsend, "What in the World Have You Done to Me, My Lover?' Sex, Servitude, and Politics among the Pre-Conquest Nahuas as Seen in the Cantares Mexicanos," The Americas 62:3 (2006): 347-389; Marie Sautron, "El lenguaje sonoro del canto náhuatl prehispánico," Hesperia: Anuario de Filología Hispánica 4 (2001): 115-136; Marie Sautron "In izquixochitl in cacahuaxochitl. Presencia y significación de un binomio floral en el discurso poético náhuatl prehispánico durante la conquista de México," Estudios de Cultura Náhuatl 38 (2007): 243-264; Miguel Figueroa Saavedra, Xopancuicatl: Cantos de lluvia, cantos de verano: estudio y edición bilingüe de cantos nahuas (Veracruz: Universidad Veracruzana, 2011); Agnieszka Brylak, "Some Remarks on the Teponazcuicatl of the pre-Hispanic Nahua," Ancient Mesoamerica 27:2 (2016): 429-439; Katarzyna Szoblik, Entre los papeles de ocelote entono mi canto yo, Quetzalpetlatzin (Mexico City; Bielsko-Biala: Centro de Estudios de Antropología de la Mujer; Universidad de Bielsko-Biala-Campana Sumergida, 2015). 
ritualized way of memorizing the past that which plays an important role in shaping and reinforcing the sense of identity in a given community. ${ }^{8}$ According to Federico Navarrete Linares, all of the altepetl (city-states) of the Basin of Mexico had their own historic traditions, which narrated the history of the region in a way differing a little from the others. ${ }^{9}$ As many of the investigators who study the Nahua narrations of the past indicate, all these stories were composed around the facts that described the process of the group's identity formation, reasserted its rights to the occupied territories, and explained its political relations with the other altepetl. ${ }^{10}$ The episodes in question, in addition to purely referential elements, frequently also contained fragments that due to their symbolic character clearly evoked the reality of myth, explaining the present reality and defining the group's identity in the light of ideology and religious beliefs.

The basic context for the enshrinement and transmission of this historic knowledge was the royal house, tecpan, whose members could control the "official" version of the altepetl's oral tradition. ${ }^{11}$ In this way, those Nahua songs that were supposed to transmit the "authorized" narration of the past were a perfect tool for construction of cultural memory and transmission. ${ }^{12}$ According to Assmann, perpetuating the memory of the past in traditional cultures included three basic elements: memorization of the information in a poetic form, its evocation during the ritual representation, and transmission via collective participation. ${ }^{13}$ In precolonial Central Mexico, the spaces for the development of these three elements were the schools, called calmecac, telpochcalli, and cuicacalli. Those were the places where Aztec adolescents were taught the songs and dances necessary to participate proficiently in ritual performances. They also absorbed the ideology, according to which the most valuable destination of every man was to die in honor of the gods, either on the battlefield or on the sacrificial stone. ${ }^{14}$ In consequence, the songs they learned presented such a death as the most desirable human destiny.

8. Jan Assmann, Pamięć kulturowa. Pismo, zapamiętywanie i polityczna tożsamość w cywilizacjach starożytnych (Warsaw: Wydawnictwa Uniwersytetu Warszawskiego, 2008), 36.

9. Federico Navarrete Linares, Los origenes de los pueblos indigenas del Valle de México. Los altepetl y sus historias (Mexico City: UNAM, 2011).

10. Navarrete Linares, Los origenes, 21-92; Angela Herren Rajagopalan, Portraying the Aztec Past (Austin: University of Texas Press, 2019), 2-3. On the relation between the oral tradition and codices, see also Camilla Townsend, Annals of Native America: How the Nahuas of Colonial Mexico Kept Their History Alive (New York: Oxford University Press, 2017).

11. Navarrete Linares, Los orígenes, 49.

12. Fray Bernardino de Sahagún, Florentine Codex. General History of the Things of New Spain, Arthur J. O. Anderson and Charles E. Dibble, eds. (Santa Fe, NM: School of American Research, University of Utah, 19501982), 2:208; Fray Diego Durán, Historia de la Indias de la Nueva España e islas de Tierra Firme, Rosa Camelo and José Rubén Romero, eds. (Mexico City: Consejo Nacional para la Cultura y las Artes [hereafter CONACULTA], 1995), 2:194-196; Damrosch, "The Aesthetics," 104-105.

13. Assmann, Pamię́ kulturowa, 69.

14. Sahagún, Florentine Codex, 2:55-67; Durán, Historia de las Indias, 2:193-196. 
To achieve this effect, the composers used a whole set of metaphorical expressions, principally based on flower- and bird-related associations. To give several examples, a war conducted with the objective of obtaining captives for sacrificial purposes was called xochiyaoyotl, "a flowery war," while death in such a war was referred to as xochimiquiztli, "flowery death." The warriors were frequently compared to eagles (quaubtli), quetzal birds (quetzalli), roseate spoonbills (tlauhquecholli), or Montezuma oropendolas (zacuanquecholli), among others. These metaphors were, in fact, directly corresponding to Aztec beliefs, according to which the warriors who died a "flowery death" were transformed into colorful birds and enjoyed their eternity sipping the nectar of the flowering trees in the land of abundance and happiness. ${ }^{15}$ The visions "painted" with the words of the songs were so picturesque that later, in the colonial era, the same flower- and bird-related metaphors were adapted for the representation of the Christian paradise. ${ }^{16}$

Another essential tool for shaping the ideology of Aztec youths was references to the cultural memory of the community. By recalling past events-migrations, foundations, wars, and genealogies, as well as the heroic deeds of the warriors who died a "flowery death" - the singers of cuicatl justified and consolidated the community's social order and system of values. As a consequence, the characters that appear in these songs are also frequently mentioned by other sources, namely the chronicles written by the descendants of the indigenous nobility, among them Fernando de Alva Ixtlilxochitl, Fernando Alvarado Tezozómoc, and Domingo de San Antón Muñón Chimalpahin Quauhtlehuanitzin, as well as in works by the Spanish clergy, such as fray Bernardino de Sahagún, fray Diego Durán, and fray Juan de Tovar. ${ }^{17}$ Among the most frequently mentioned characters are famous Aztec governors such as Motecuhzoma Ilhuicamina, Axayacatl, and Motecuhzoma Xocoyotzin, and two of the most distinguished rulers of Tetzcoco, Nezahualcoyotl and his son, Nezahualpilli.

The historical identity of these figures is, therefore, not in question. However, as has been mentioned above, cultural memory tends to elaborate its own version of the facts and shapes its heroes according to its own needs. For this reason, when analyzing the figures of heroes commemorated in songs, the following questions should be posed: To what extent is the image of these warriors presented in cuicatl

15. Sahagún, Florentine Codex, 2:49-50.

16. Louise Burkhart, "Flowery Heaven: The Aesthetic of Paradise in Nahuatl Devotional Literature," Res: Anthropology and Aesthetics 21 (1992): 88-109.

17. Fernando de Alva Ixtlilxochitl, Historia de la nación chichimeca (Madrid: Dastin Historia, 2000); Fernando Alvarado Tezozómoc, Crónica mexicana (Madrid: Dastin Historia, 1997); Domingo de San Antón Muñón Chimalpahin Quauhtlehuanitzin, Las ocho relaciones y el memorial de Colbuacán (Mexico City: CONACULTA; Cien de México, 1998); Sahagún, Florentine Codex; Durán, Historia de las Indias; Juan de Tovar, Historia y creencias de los Indios de México (Madrid: Miraguano, 2001). 
a reflection of their real lives? How were their stories reshaped by the singers to meet expectations of the tecpan? What was the mechanism that underlay these creations? The following case study of Tlacahuepan, one of the most distinguished warriors mentioned by the cuicatl, is aimed at exploring answers to these questions.

\section{Tlacahuepan, Hero of the AzTec Songs}

The name Tlacahuepan is a compound of two nouns: tlaca[tl], "a man, person, or nobleman," and huepan [tli], translated by Fray Alonso de Molina as "a beam to be carved" or "dragged wood" and also clearly related to the verb buepana "to drag wood." 18 The whole name could thus be translated principally as "Human Beam," and alternatively as "Man Dragged as Wood."

The character of this name is evoked in the songs that are basically dedicated to war themes, for example, Yaocuicatl, "War Song," or Yaocuicacuextecayotl, "Huaxtec-style War Song," among many others. ${ }^{19}$ The following lines present several samples of text that illustrate the principal linguistic tools and metaphorical references employed by the composers of the cuicatl when referring to this hero. The first fragment comes from the song entitled Ycuic neçahualpilli yc tlamato buexotzinco. Cuextecayotl, Quitlali cuicani Tececepoubqui, or "The song of Nezahualpilli when he took captives in Huexotzinco. [It tells of] the Huastec themes, it was written down by the singer Tececepouhqui." From the song:

The owners of the mounds. The owners of the captives make those of the burnt houses dance. The owners of the flowery drums, the owners of the precious shields $\mathrm{Et}^{\mathrm{a}}$.

He is already bleeding, my nobleman, the golden one, the Huastec Lord, the owner of the sapota skirt, Tlacahuepan. He is rejoicing in Quenonamican aoyyaye aye oyayayaa

With the flowery liquor of war, he is drunk, my nobleman, the golden one, the Huastec Lord $\mathrm{Et}^{\mathrm{a}} .20$

The image created by this song is very vivid and picturesque. While the victorious warriors, "the owners of the flowered drums, the owners of the precious shields," begin to prepare their captives for sacrifice by making them perform a captive

18. Fray Alonso de Molina, Vocabulario en lengua castellana y mexicana, y mexicana y castellana (Mexico City: Porrúa, 1992): huepantli, 2:115v, 1:117v, 13v; huepana 2:156v, 1:13v.

19. Miguel León-Portilla, ed., Cantares mexicanos (Mexico City: UNAM, 1994), fol. 64r, fols. 65r-66r.

20. Ye tlatileque ya yolimaleya anca quimittotia in ibuatzalhuã huebuexochibuaque o ça queçal Eta. Ye ço yahqui nopillotzin coçahuic cuextecatotec tzapocueyeha tlacahuepan motimalohuaya, quenonamicã aiyyaye aye oya yayaa. Yaoxochioctica yhuintitiaqui aa nopillotzin coçahuic cuextecatotec Eta. Cantares mexicanos, fols. 55v-56r, paleogr. Bierhorst, Cantares, 326. English translation is by the author. 
dance, on the battlefield there lies one of the Aztec captains, Tlacahuepan. He fought very well, for "with the flowered liquor of war he is drunk," and yet he was hurt, and now, still bleeding, he is passing to the eternal glory, expressed here with one of the Nahuatl terms for the otherworld, Quenonamican, "The Mysterious Place." The text of the song describes him with two titles, which require some explanation: Cuextecatotec, "the Huastec Lord," and nopillotzincoçahuic, tzapocueyeha, "my nobleman, the golden one, the owner of the sapota skirt.”

Cuexteca is the name with which the colonial sources refer to the inhabitants of Cuextlan, the land known today as the Huasteca. It is situated on the coast of the Gulf of Mexico, extending approximately from the Cazones River in the south to the Soto de la Marina River in the north. ${ }^{21}$ Due to its warm climate and lush vegetation, the Huasteca was considered by the Nahua as a land of fertility. The informants of fray Bernardino de Sahagún describe this land: "And there are all kinds of food; many different kinds of food grow there, none of which appear here, [such as] the one named quequexquic. Many other wonderful [plants] grow there; the sweet potato every month. There are all different kinds of cotton. It is called the land of food, the land of flowers."22

What is more, Hernando de Alvarado Tezozómoc reports that the coastal regions were obliged to pay tribute to Tenochtitlan with various luxurious goods, such as "precious stones, emeralds, other chalchibuitl stones, gold, precious plumage of different types and colors, different types of precious birds, called xiubtototl, tlauhquechol, tzinitzcan . . . and precious birds called zacuan and toznene, various species of parrots, and ayocuan, eagles. ${ }^{23}$

All the bird species enumerated by Alvarado Tezozómoc appear in various Aztec songs as metaphors for the warriors who died in a battle or sacrifice. They could appreciate the eternal happiness of the otherworld on a vast plain, full of woods, situated in the place where the Sun rises, that is, in the east. ${ }^{24}$ Thus, it seems natural, that the eastern coastal plain of the Huasteca, with its lush vegetation and abundance of bird species, must have been conceptualized by the Nahua as

21. Felipe Solís Olguín, "Los huastecos," Arqueología Mexicana 14:79 (2006): 28-31.

22. Aub ixqujchvnca in tonacaiotl, ocmjectlamantli, in vmpamochioaxuchiqualli, in atlenjcanneci, in jtoca, quequexqujc: ocmjec in maviztic, vmpamochioa, in camotli, in jxqujch in metztli: mocha vnca in nepapanichcatl, in xuchitl, mjtoa Tonacatlapan, xuchitlapan. Sahagún, Florentine Codex, 10:185. Translation is by Anderson and Dibble.

23. piedras preçiosas, esmeraldas, otras piedras chalchibuitl, oro, preçiada plumeria de diversas maneras y colores, de diversas maneras de preçiada abes bolantes, nombrados xiubtototl, tlauhquechol, tzinitzcan (...) y preçiadas abes bivas <que > llaman zacuan y toznene, papagayos de muchas maneras, y ayocuan, águilas. Alvarado Tezozómoc, Crónica mexicana, 91. Translation is by the author.

24. Fray Bernardino de Sahagún, Historia general de las cosas de la Nueva España, (Madrid: Sociedad Quinto Centenario - Alianza Editorial, 1988), 1:222-223. 
the threshold of the House of the Sun. Tlacahuepan, whom the analyzed fragment presents as dying, can, then, be described as the Huastec Lord because he is about to depart to the House of the Sun. Alternatively, maybe he is already there, transformed into one of the tropical birds, enjoying Tonacatlapan, xuchitlapan, the "land of food, the land of flowers." 25

On the other hand, it must be remembered that the inhabitants of the Huasteca, called by the Nahua Cuexteca or Tohneyome, or "People like us," according to informants of Sahagún, were stereotyped by the inhabitants of the central plateau as libertines and drunkards. ${ }^{26}$ According to one of the Nahua myths, in the primordial times, when all groups were still travelling together, the leader of the Huastecs, called Cuextecatl, got drunk with pulque and denuded himself in the sacred place of Mount Chichinauhia. As a result of this lack of respect for divinity, he and his people, the Huastecs, were forced to separate themselves from the rest of the migrants and go back to the place from whence they had come, that is, to the coast. ${ }^{27}$ Like this mythic Huastec lord, Tlacahuepan is described in the song as metaphorically besotted with the liquor of war, which forced him to separate himself from those who survived and follow the road toward the eastern shore. As for the sexual excess of the Huastecs, the relation between Tlacahuepan and another "Huastec Lord," Tobneyo, will be discussed in subsequent sections.

Another important expression, nopillotzin coçahuic, tzapocueyeha, "my nobleman, the golden one, the owner of the sapota skirt," makes reference to one of the Aztec gods, Xipe Totec, "Our Lord, the Owner of the Skin." According to the informants of Sahagún, the cult of this god was brought to Central Mexico from the Huasteca, for which reason the title of the Huastec Lord, discussed above, could be also treated as one of the titles of Xipe. ${ }^{28}$ This and the other expressions are in fact the enumeration of the characteristics of this deity. The golden-color skin of the flayed men worn by Xipe on one hand refers to the color of maize, underlining his relationship with agriculture; on the other, it is a sign of his strong connection with gold and goldsmiths, of whom he was patron. $^{29}$ The skirt made of the sapota leaves was another characteristic feature of Xipe Totec's image (see Figure 1).

For the Aztecs, Xipe Totec, also known as Tlatlaubqui Tezcatlipoca, or "Red Tezcatlipoca," was the god of spring, vegetation renewal, and new life

25. Sahagún, Florentine Codex, 10:185.

26. Sahagún, Florentine Codex, 10:193.

27. Sahagún, Florentine Codex, 10:185-186, 193-194.

28. Sahagún, Historia general, 1:88

29. Elizabeth Baquedano, "El oro azteca y sus conexiones con el poder, la fertilidad agrícola, la guerra y la muerte," Estudios de Cultura Nábuatl 36 (2005): 359-381. 
FIGURE 1

Xipe Totec Wearing Flayed Yellow Skin, the Sapota Skirt and the Headdress of the Roseate Spoonbill Feathers

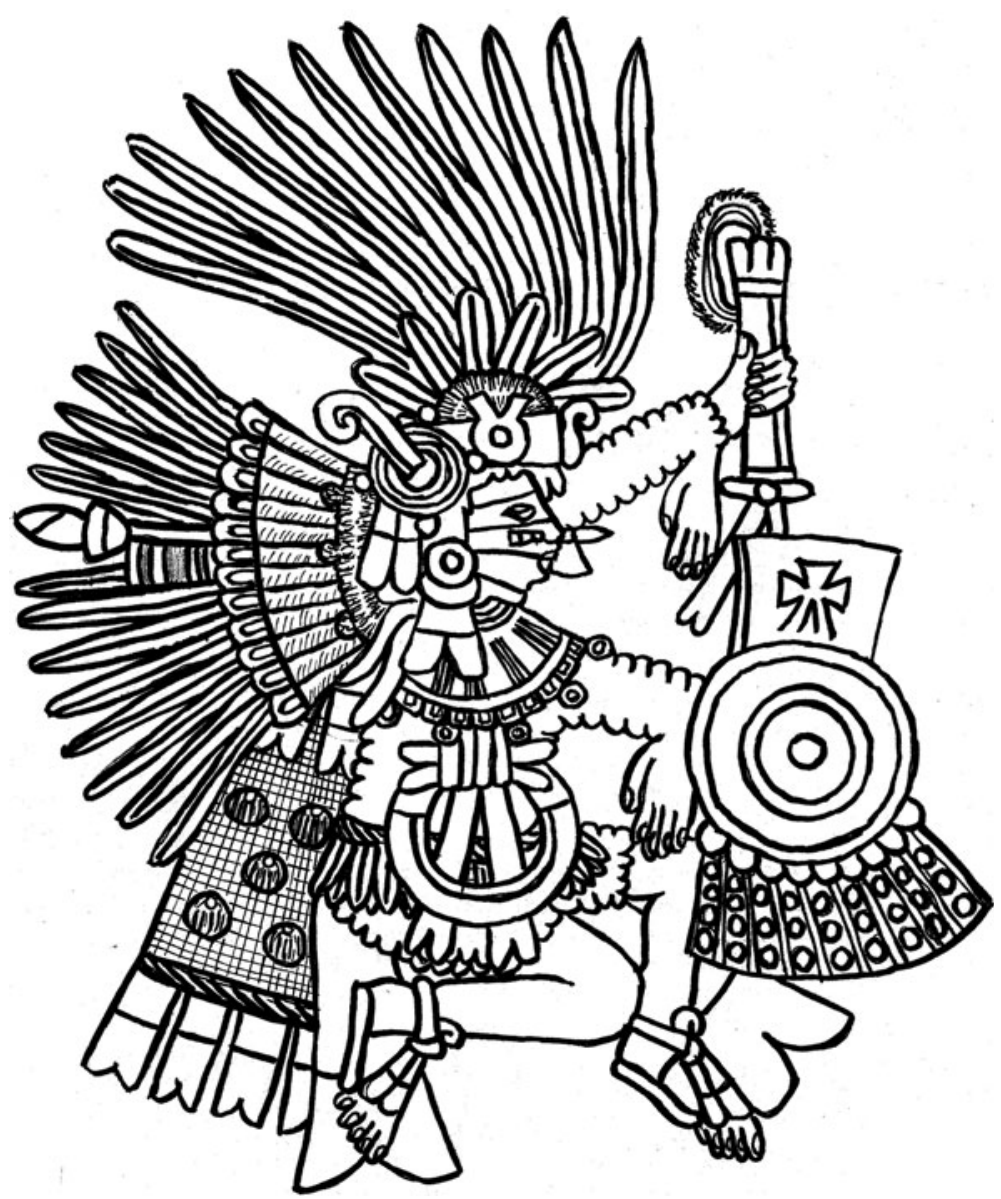

Source: Codex Borbonicus (1980) Códice Borbónico. Manuscrito mexicano de la biblioteca del Palais Bourbon (Libro adivinatorio y ritual ilustrado),Mexico, Siglo XXI, f. 14, redrawn by Katarzyna Szoblik

emerging from death. ${ }^{30}$ Thus, it can be stated that by comparing Tlacahuepan to Xipe Totec the singer meant to show him as undergoing the crucial transformation-when the life essence, which until that moment had been enclosed in the "shell" of his body, was finally emerging to start a new life as one of the glorious Sun companions.

30. Ángel María Garibay Kintana, Teogonía e historia de los mexicanos: tres opuisculos del siglo XVI (Mexico City: Porrúa, 1979), 23; Peter T. Markman and Roberta H. Markman, Masks of the Spirit: Image and Metaphor in Mesoamerica (Berkeley: University of California Press, 1989), 117. 
Xipe was also a god related to war, nobility, and death. In fact, at least three of the Aztec supreme rulers, Axayacatl, Ahuitzotl, and Motecuhzoma Xocoyotzin, are reported by the sources to wear the insignia of Xipe Totec in war campaigns. ${ }^{31}$ According to Guilhem Olivier, by adorning themselves with the emblems of various divinities, the buey tlatoque were identifying themselves with their most important characteristics in order to recreate the primordial divine influence on the life of the world. ${ }^{32}$ Kay Read goes even further, claiming that the individual who put on a ritual costume of a given divinity was becoming this divinity, as "every mask, effigy, and object embodied a particular force. To wear it meant to take on its face (ixtli), to become its identity."33 In other words, the Aztec huey tlatoque, by wearing the insignia of Xipe Totec, were in fact becoming the teixiptla, "local embodiment" of this divinity. ${ }^{34}$

Maybe it was for this reason that, as fray Toribio de Benavente O Motolinía states, the war insignias of the huey tlatoani were not to be used by any other man, on pain of death. ${ }^{35}$ However, Diego Durán reports that in the campaign of Huexotzinco, which is told in the song analyzed here, Motecuhzoma Xocoyotzin honored his brother Tlacahuepan with the insignia of Xipe Totec. In this divine array, he was to lead the Tenochca troops to start the war in which he fell. ${ }^{36}$

The second fragment to be analyzed comes from the text titled Yaocuicacuextecayotl, "The War Song of Huastec Style/on Huastec Themes.” As can be seen in the following lines, again the underlying motif is Tlacahuepan's flowery death:

Duck from the place of preciousness, you went flying around, you, my flowered great man, Tlacahuepantzin. He just followed their father to Quenonamican.

To the coast he is going to sing, he is going to speak, flowery liquor of precious water makes him drunk. He is going to chirp among his fellow quecholli birds, the noblemen, the Huastecs, in the land of maguey. ${ }^{37}$

31. Codex Cozcatzin (Mexico City: Instituto Nacional de Antropología e Historia; Universidad Autónoma de Puebla, 1994), fol. 15r; Codex Vaticanus A (Mexico City: Graz-México: ADEVA- Fondo de Cultura Económica, 1996) fol. 83v; Carlos J. González, Xipe Tótec. Guerra y regeneración del maiz en la religión mexica (Mexico City: Fondo de Cultura Económica, 2011), 338-343.

32. Guilhem Olivier, Mockeries and Metamorphoses of an Aztec God: Tezcatlipoca, "Lord of the Smoking Mirror" (Boulder: University Press of Colorado, 2008), 207-208).

33. Kay Read, Time and Sacrifice in the Aztec Cosmos (Bloomington: Indiana University Press, 1998), 147.

34. Molly Basset, The Fate of Earthly Things (Austin: University of Texas Press, 2015).

35. Fray Toribio de Benavente o Motolinía, Memoriales. Libro de oro (Mexico City: Colegio de México, 1996), 484.

36. Durán, Historia de las Indias, 2:433.

37. In quetzallaxomotzin tonpapatlantiya tinoxochibueyotzin in tlacahuẽpantzin aya çã quitocac ỹta quenonamicã Anã. Aytic yen ocuica a ontlatobua o ayaye in quetzalaxochioctli quitlabuanaya onchachalacaya yquecholpohuan y teucpipilti yn cuexteca y meEtlan. Cantares mexicanos, fols. 65r-66v, paleogr. Bierhorst, Cantares, 362. English translation is by the author. 
The first of the expressions with which the singer refers to Tlacahuepan is quetzallaxomotzin, which can be translated as "duck from the place of preciousness." The basic noun, xomotl, is explained by Francisco Javier Clavijero as a "certain aquatic bird, whose feathers were used by the ancient people in their clothing." 38 The custom of applying the feathers of different birds, such as quetzal, heron, roseate spoonbill, or eagle in the attire of warriors and noblemen was a common practice among the Aztecs. However, the reference to Tlacahuepan as an aquatic bird, moreover one that comes from the region of the precious things, would be another allusion to the Huasteca, known also among the Nahua as the place from which the cultivation of the maguey plant came. Thus, it is there, "in the land of the maguey," the coastal region, where Tlacahuepan is about to make his final step to follow his ancestors to Quenonamican. He can already enjoy the company of other deceased noblemen, described as his fellow quecholli birds and the Huastecs.

As for the quecholli, bird names that include this term are plentiful in Nahua songs. Among the most frequent there are teoquechol, zacuanquechol, tlauhquechol, and xopanquechol. According to Garibay, all these names-some of which make reference to actual bird species, while the others seem to be poetic creations - are meant, in fact, to recall a general notion of a bird whose feathers are red or light pink, similar to the light, flame, and Sun at dawn. According to Legend of the Suns, the darts given by the Sun to the Mimixcoa at the beginning of the times in order to initiate the human sacrifice were made precisely of the plumage of precious birds. ${ }^{39}$ These darts, metaphorically created by the Sun at the dawn of the world, could thus be compared to sunbeams at daybreak and the precious birds become perfect metaphors for the deceased warriors, who are accompanying the Sun and sharing its characteristics. $^{40}$

Among all these bird species special importance is given to the tlauhquecholli, which is the Nahuatl name for the roseate spoonbill. As Leonardo López Lujan and Guilhem Olivier observe, the Nahua considered this particular species of bird as ruling over other birds, and thus, belonging to the tlatoque of the animal world. Others were iztacmazatl or white deer, who was the ruler over all deer, atotolin or pelican, who governed the aquatic birds, and tecubtlacozaubqui, the rattlesnake, which was considered chief of all the snakes. ${ }^{41}$ As such, the

38. Francisco Javier Clavijero, Historia antigua de México (Mexico City: Porrúa, 1945).

39. John Bierhorst, History and Mythology of the Aztecs: The Codex Chimalpopoca (Tucson: University of Arizona Press, 1992), 150.

40. Ángel María Garibay Kintana, Veinte himnos sacros de los nahuas (Mexico City: UNAM, 1958), 161.

41. Leonardo López Lujan and Guilhem Olivier, "De ancestros, guerreros y reyes muertos. El simbolismo de la espátula rosada (Platalea ajaja) entre los antiguos nahuas," in De saber ha becho su razón de ser. . Homenaje a Alfredo 
tlauhquecholli was a perfect metaphor for the nobility. In fact, the headdress of its plumage also formed part of Xipe Totec's attire (commented on above in relation to Figure 1) and of the insignia worn by the rulers on the battlefield. What is more, as a predatory bird known to catch and eat its prey alive, tlauhquecholli was considered similar to jaguar and eagle, the two principal symbols of the Aztec warriors.

It is no surprise then, that tlauhquecholli is the name given to Tlacahuepan in the next of the fragments presented here. The text comes from the song entitled Mexica xopancuicatl, "Mexica Summer Song":

Your roseate spoonbill is getting anxious. Nobleman, Tlacahuepan, your fame is growing. You are gone. The Lord of Turquoise, the Fire-Eagle has come to shave you.

Under your charge the war is now sparkling and boiling, a noise of crackling flames spreads all around. You have gone to hide yourself, our Lord, the golden flowers are spreading around where is now my Lord Tlacahuepan. ${ }^{42}$

Like a bird free to fly away towards the Sun, so is Tlacahuepan becoming anxious to abandon the "shell" of his body and fly to meet the Lord of Turquoise, the Fire-Eagle. He has been captivated by the Sun itself, which is expressed in the act of being "shaved" by this god; this ritual will be described in subsequent sections. At the same time, under his charge, the battle is still going on, painted here with the metaphors of crackling fire on one hand and summer-flowery scenery on the other.

To sum up this part, these several short but highly eclectic metaphors reveal the rich imagery created by the Nahua state ideology around this warrior's death on the battlefield. On one hand, Tlacahuepan embodies such key concepts as nobility, power, courage, and sacrifice; on the other, his death evokes the notions of glory, happiness, abundance, and freedom. There is, however, an important question to be asked at this point: Why him? Why was it Tlacahuepan-and not any other of the many noblemen who had fallen in numerous war campaigns held by Tenochtitlan-the one who became so famous? The answer can be found in the narrations of the events mentioned

\footnotetext{
López Austin, Eduardo Matos Moctezuma and Ángela Ochoa, eds. (Mexico City: Secretaría de Cultura, Instituto Nacional de Antropología e Historia, UNAM, 2017), 181.

42. Çan motlaubquechol moyaubtiuh on yn ica toya in titepiltzin a yn Tlacahuepan mopopoyaubtaya tiyaqui yancohuin mitzhualxima Xippilli Quaubtlehuanitl ahuayya ohuaya Can mopan iya ye oncã milini poçoni yehuaya $\tilde{y}$ tlachinollion $\tilde{y}$ cocomocatima ye tonmotlatian totec teocuitlaxochitl momoyahua ye oncan Nopiltzino in tlacahuepani ahuayya a on abuaya. Cantares mexicanos, fol. 6lv, paleogr., in Bierhorst, Cantares, 348. English translation is by the author.
} 
above, as recorded by various colonial chroniclers on the basis of the indigenous codices and oral tradition.

\section{TLACAHUEPAN AND THE HUEXOTZINCO WAR}

The war of Huexotzinco, which was so important for the inhabitants of the Basin of Mexico that it became one of the themes repeatedly recalled in sixteenth-century Nahua songs, took place shortly before the arrival of Spaniards, under the rule of the last of the Tenochtitlan tlatoque, Motecuhzoma Xocoyotzin. The colonial chronicles provide two basic versions of this war, one focusing its attention on the role of Tenochtitlan and the other on the role of Tetzcoco. Although the first of the songs quoted above refers in its title to the Tetzcoco ruler Nezahualpilli, the version of the story proposed by Fernando de Alva Ixtlilxochitl does not mention Tlacahuepan by name. For this reason, the main attention will be given here to the works by Diego Durán and Hernando de Alvarado Tezozómoc. ${ }^{43}$ These two sources are judged by investigators as highly "suspicious," first because of the strong Christian influence visible in them, especially in Durán's Historia, and second because of their clear bias toward the Tenochca point of view and the abundant recurrences of mythical reality creeping into the historical facts. ${ }^{44}$ Yet, it is precisely for this last reason that they are of great interest for the present study, which aims at tracing the methods and strategies used by Aztec cultural memory to construct its own vision of the past.

According to these relations, the conflict in question was in fact a flowery war, xochiyaoyotl. As it is described by Durán, Motecuhzoma Xocoyotzin, having conquered most of the neighboring cities and finding no other reasons for war, sent his messengers to Huexotzinco with the proposal of a combat "for exercise and diversion. ${ }^{\$ 5}$ Thus, it was not a conflict for lands or domination, but a planned battle, held in order to practice warfare and to honor the gods. Motecuhzoma did not mean to participate in it directly but delegated the power to his brother Tlacahuepan. The visible sign of this was an act of handing him over the insignia of Xipe Totec. Accordingly, both Alvarado Tezozómoc and Durán report that while receiving those gifts Tlacahuepan was already sensing his imminent death, so, bidding farewell to his royal brother, he

43. Durán, Historia de las Indias, 1:495-500; Alvarado Tezozómoc, Crónica mexicana, 386-395; Alva Ixtlilxochitl, Historia de la nación, 211-213.

44. Sylvie Peperstraete, "El cihuacoatl Tlacaélel: su papel en el imperio azteca y su iconografía," in Símbolos del poder en Mesoamérica, Guilhem Olivier, ed. (Mexico City: UNAM, 2008), 376.

45. Durán, Historia de las Indias, 1:495. 
entrusted his family to him. ${ }^{46}$ The battle was fierce, and many of the Tenochca and their allies fell.

Seeing this bloodbath of his companions, Tlacahuepan decided to gain his fame by breaking through the enemy's formation. He was immediately surrounded by the Huexotzinca but would not surrender for a long time, killing every warrior who came close to him. Finally, when he felt that he had no more energy to defend himself, he threw his weapons aside and turned himself in to the Huexotzinca. Both Alvarado Tezozómoc and Durán describe the moment of his death, underlining the fact that he was dismembered on the battlefield and that the Huexotzinca then took parts of his body as relics. When Tlacahuepan was killed, the Mexica troops tried to fight for some time longer, but soon they were forced to retreat. ${ }^{47}$

This story seems to be like those of the many wars that took place in the Basin of Mexico in preconquest times, and yet the structure of this narration reveals some of the symbolic meanings given to it by the cultural memory of the Nahua. First, by wearing the insignia of Xipe Totec, Tlacahuepan was made not only to represent the tlatoani on the battlefield, but also to share an identity with Xipe, maybe even becoming his teixiptla. Molly Basset translates this term generally as "local embodiment of the divinity," but at the same time indicates that in the sources its exact meaning would be dependent on the context. In this way, in military contexts teixiptla could refer to "a military delegate" of tlatoani, while in the ritual ones this relation between the source of power and its local embodiment would be more direct: "A teixiptla is the being whom it embodies; it is neither an impression nor a representation of that thing."48

The situation in which Tlacahuepan is converted into teixiptla in fact covers both of these contexts. The flowery wars, such as the one held in Huexotzinco, although they certainly had political implications, were different from the "regular" conflicts. Due to their ritualized character and underlying religious motivation, they could be considered as a form of religious ritual in which the sacrifice to the gods took a spontaneous form of death on the battlefield. Tlacahuepan was tlatoani's delegate to perform the role of the local embodiment of Xipe Totec, and repeat the action of this god who, according to the myths, was the initiator of the xochiyaoyotl in primordial times. In this way the story of his death became a part of the Nahua historiographic framework, based on the cyclical repetition of certain motifs and the re-elaboration of fixed

46. Alvarado Tezozómoc, Crónica mexicana, 389-390; Durán, Historia de las Indias, 1:496.

47. Alvarado Tezozómoc, Crónica mexicana, 390-391; Durán, Historia de las Indias, 1:497.

48. Basset, The Fate, 132-133. 
narrative structures, both of which had their origin in the primordial reality of myth.

As the Annals of Cuaubtitlan inform, the first xochiyaoyotl was organized as a prelude to the first celebration of the Tlacaxipehualiztli, the "Flaying of Men" feast, which was one of the omens foretelling the fall of Tollan, a great Centro-Mexican civilization that preceded the Aztec domination in the Basin:

13 Reed [1063]: At this time there were many evil omens in Tollan. At this time, too, there was beginning of the war that the devil Yaotl started. The Toltecs were engaged [in battle] at a place called Nextlalpan. And when they had taken captives, human sacrifice also got started, as Toltecs sacrificed their prisoners. Among them and in their midst the devil Yaotl followed along. Right on the spot he kept inciting them to make human sacrifices.

And then, too, he started and began the practice of flaying humans. ${ }^{49}$

According to various narratives, which will be commented on in more detail below, the fall of Tollan was preceded by the introduction of different types of human sacrifice to this once peaceful place. Like the mythical Yaotl, a title given mostly to Tezcatlipoca but also to Xipe Totec, Tlacahuepan incites both the Tenochca and the Huexotzinca warriors to fight and take captives. As in the mythical dimension, it was crucial to persuade the Toltecs to undertake human sacrifices. Tlacahuepan, as teixiptla of Xipe Totec, initiates the Tlacaxipehualiztli feast with the end his own life, a sacrifice of which he was apparently conscious from the very moment in which he donned the god's insignia. After a fierce fight he was killed in a way resembling the sacrifice held during the Flaying of Men. First of all, the hearts extracted from the captives during Tlacaxipehualiztli were offered to the Sun, which, in the description of this feast, Sahagún's informants call “The Lord of Turquoise, The Fire-Eagle."

This is the same title with which one of the songs quoted above refers to the Sun when saying to Tlacahuepan: "The Lord of Turquoise, The Fire-Eagle, has come to shave you." The act of shaving the head of the captives by their captors was one of the preparatory rites celebrated before the sacrifice, which might suggest that the song presents Tlacahuepan as the captive of the Sun itself. ${ }^{51}$ Finally, the sacrificed captives were taken to local temples, where their bodies were

49. 13 acatl. Iniquac $\{$ miec $\}$ mochiubtin onca tetzahuitl in tollan, ø niman no ompa peub y yaoyotl inquitzinti Diablo yaotl, ompa in mitoa nextlalpan qui mixnamicque in Tolteca, aub in otlamato niman no oncan peub in tlacamictiliztli in quin mictique in malhuan tolteca in tzallan in nepantla icatinenca in Diablo yaotl inic huel oncan quenitlabuiltitinenca, inic tlacamictizque. Aub niman no contzinti compehualti in tlacaxipehualiztli. Bierhorst, History and Mythology, 40.

50. Sahagún, Florentine Codex, 2:47.

51. Sahagún, Historia general, 1:107. 
dismembered and treated as relics, parts of which were then ritually eaten. ${ }^{52}$ Although neither Alvarado Tezozómoc nor Durán report on the ritual anthropophagy among the Huexotzinca after the battle, it might be supposed, taking into consideration the information of how they divided the remains of the Mexica captain among themselves, that the rest of the story was self-evident for the Nahua public and needed no extra verbalization. On the other hand, it should be remembered that the sacrifices celebrated during the Flaying of Men, apart from killing war captives, also included the death of Xipe Totec's teixiptla, that is, a person who personified the god in question by wearing his attire. What is more, Durán also reports that the principal offerings during this feast included golden-yellow bunches of corncobs wrapped in sapota leaves, which symbolically also might have represented "the golden one, the Huastec Lord, the owner of the sapota skirt."

In other words, the figure of Tlacahuepan as presented in songs and stories through different symbolic underpinnings evokes the nature of Xipe Totec, as well as the victims, offerings, and rituals celebrated during the Flaying of Men. His death in the flowery war between Tenochtitlan and Huexotzinco seems to be the ritual repetition of the mythical initiation of the cult of Xipe Totec, Tlacahuepan being at the same time the teixiptla of the god and the first archetypal victim. This supposition may be supported also by the fact that in Alvarado Tezozómoc's and in Durán's relations the story has its direct continuation in the war waged by Tenochtitlan against the cities of Yancuitlan and Çoçolan. As these chroniclers recount, the decision to organize this campaign was taken by Motecuhzoma soon after the news of Tlacahuepan's death had reached him. As a result, both cities were conquered with ease and with nearly no loss of life on the Mexica side, while their inhabitants were taken captive, and dedicated to dying in the Tlacaxipehualiztli feast. ${ }^{54}$

\section{Tlacahuepan AND THE CHALCAN WAR}

As has already been suggested, one of the components of the Nahua understanding of history was the idea of circularity of time, in which certain events could repeat, recreating the first primordial actions of gods. It seems that Tlacahuepan's death was one of these: according to the sources, years before the confrontation between the Mexica troops and their Huexotzinca enemies on the plains of Atlixco another battle was held, in which the high-ranking

52. Sahagún, Florentine Codex, 2:47.

53. Durán, Historia de las Indias, 2:105.

54. Alvarado Tezozómoc, Crónica mexicana, 394-396; Durán, Historia de las Indias, 2:497-500. 
nobleman of this name was killed. It was a campaign organized by Tenochtitlan and its allies against Chalco. Both Durán and Alvarado Tezozómoc state that the reason for initiating this war was Tenochtitlan's goal to conquer Chalco, which at that time was one of the few still unconquered places in the region.

An excuse for provocation was soon found in the construction of the temple of Huitzilopochtli. ${ }^{55}$ It was a great project to which all the subject city-states were supposed to contribute with some kind of tribute, either by providing materials for construction or by delegating the workforce. Messengers were also sent to Chalco to ask for the rocks and stones necessary for the temple sculptures, but the city rulers denied the request. As a result, a prolonged conflict, separated by numerous truces, began. As both chroniclers recount, the crucial confrontation took place in the days preceding the feast in honor of Camaxtli, who was the patron god of Chalco, Huexotzinco, and Tlaxcalla, and to whom the Chalca had promised to make offerings with the blood of the Tenochca warriors. The Tenochca, who also had planned a bloodbath during the consecration of the temple of Huitzilopochtli, and another during the approximating feast of Xocotl Huetzi, made a similar vote to their gods. The battle turned out to be unexpectedly long, arduous, and cruel. It ended without a decisive winner, as both parties lost many lives and many important warriors were taken captive, among them Motecuhzoma Ilhuicamina's brother, Tlacahuepan. ${ }^{56}$

As recounted in the Crónica mexicana, once the Chalca noticed that he was not dead, as they had thought, they decided not to kill him but rather to ask him to stay among them and to act as the ruler of the other Mexica captives. Hearing this offer, Tlacahuepan responded that first he desired to entertain himself with his companions. For this purpose he needed a tall beam and some instruments, which the Chalca promptly brought him. Tlacahuepan climbed to the top of the beam and once he had gotten into position the other Tenochca warriors initiated a sad song in a low tone and started to dance around the beam. In the next moment the completely surprised Chalca heard Tlacahuepan's voice pronouncing an ominous prophecy: "Lords of Chalco, today I buy you for my slaves, you are to serve and pay tribute to our sons and grandsons, the Mexicans. And be aware that what I've just said is sure to become true." ${ }^{\$ 57}$ These words could seem an idle threat of a defeated man facing his end, and yet they must have been meaningful to the spectators of this scene, for the Chalca became really terrified. As told by Alvarado Tezozómoc, in panic, they started to give him signs and tried to stop him, promising to make him a ruler

55. Durán, Historia de las Indias, 1:183-202; Alvarado Tezozómoc, Crónica mexicana, 153.

56. Durán, Historia de las Indias, 1:183-202; Alvarado Tezozómoc, Crónica mexicana, 153.

57. Alvarado Tezozómoc, Crónica mexicana, 133-134. 
not only over the Mexica, but over all of them, but it did not work. Tlacahuepan bade farewell to his companions, advising them to continue their song, and threw himself down from the top of the beam. ${ }^{58}$

The fear of the Chalca, who at first glance seemed to dominate the situation, points to the symbolic aspects of this story. The death of Tlacahuepan is not a suicide, but a planned human sacrifice of great ritual and magical power, flowing out from its bonds to the reality of myth. Again, Tlacahuepan's voluntary death repeats the mythical initiation of the human sacrifices, celebrated within the framework of the Aztec solar calendar, ximbpohualli, which in primordial times brought destruction to the famous city of Tollan. By arranging his death in this particular manner, Tlacahuepan imposes on the Chalca the celebration of the Xocotl Huetzi ("Fruit Falls Down") feast, he himself being the principal sacrificial victim. ${ }^{59}$

As told in various sources, the central point of the Xocotl Huetzi celebrations was the high beam called xocotl, prepared in advance during the preceding feast of Tlaxochimaco. $^{60}$ The similarity between the festive beam and the one demanded from the Chalcas by Tlacahuepan is quite apparent. On the top of the beam the ritual specialists situated the teixiptla of the xocotl (fruit), which according to different sources could have had one of the following forms: a bundle of weapons, a multicolor paste bird, a human figure decorated with ritual paper, or a captive decorated with the insignia of Otontecuhtli, "The Lord of the Otomi," the patron god of the warriors. ${ }^{61}$ Thus, again, Tlacahuepan is converted into the teixiptla of the divine force to whom the celebrated feast was dedicated. As Sahagún's informants report, once the beam was ready, the captives who were dedicated to die in the fire sacrifice, like those of the Tlacaxipehualiztli feast, started their ritual dance together with their captors. $^{62}$ They were dressed like the Mimixcoa, the 400 gods created in primordial times to initiate the sacred war and become the first human sacrificial victims. ${ }^{63}$ This brings to mind the dance and song performed by

58. Alvarado Tezozómoc, Crónica mexicana, 134.

59. Michel Graulich, Mitos y rituales del México Antiguo (Madrid:Istmo, 1990), 416-419; Michel Graulich, Ritos aztecas: las fiestas de las veintenas (Mexico City: Instituto Nacional Indigenista, 1999), 412-415.

60. Sahagún, Florentine Codex, 2:104-109; Durán, Historia de las Indias, 1:271-273; Codex Borbonicus, Códice Borbónico. Manuscrito mexicano de la biblioteca del Palais Bourbon (Libro adivinatorio y ritual ilustrado), publicado en facsimil (Mexico City: Siglo XXI, 1980), 29; Elizabeth Hill Boone, The Codex Magliabechiano and the Lost Prototype of the Magliabechiano Group, Elizabeth Hill Boone (Berkeley; Los Angeles; London: University of California Press, 1983), 77.

61. Tovar, Historia y creencias, 27-28; Durán, Historia de las Indias, 1:125-126); Sahagún, Florentine Codex, 2:105; Codex Magliabechiano, fols. 76-77.

62. Sahagún, Florentine Codex, 2:106.

63. Graulich, Mitos y rituales, 411 . 
Tlacahuepan's companions around the beam. Like the mythical Mimixcoa, all of them were later sacrificed by shooting with arrows.

One of the critical moments of Xocotl Huetzi was the race to the top of the beam in which the young warriors could achieve fame similar to that given to those who had taken captives on the battlefield. Once on the top of the beam, the winner of the race threw the xocotl down, so that it broke into many parts that were then distributed among the participants. As soon as its pieces fell among the people, there started a clamor, tumult, and war cry, as if a real fight was going on. ${ }^{64}$ This ritual battle, initiated by the crashing down of the xocotl, in Chalco took the form of a real conflict launched by Tlacahuepan's death. Once Motecuhzoma had learned about it, he sent all his forces against Chalco. The war ended with the conquest of Chalco, and the captives taken by the Tenochca were then sacrificed during the feast of Xocotl Huetzi in Tenochtitlan.

In both stories narrated above, Tlacahuepan, "The Human Beam," performs a double role. On one hand, as a valiant warrior, unafraid of death and devoted to his people and his values, he becomes a perfect educational model to be presented to the Aztec youths during dance and song classes. On the other hand, the last moments of his life and his sacrificial death are described in a way that gives them highly symbolic meaning. In the oral narrations of these events, which were the source of knowledge for the written texts, Tlacahuepan was presented as the one who voluntarily decided to perform a role of teixiptla of the god, the role which in most of the ritual contexts of xiuhpohualli was connected to the sacrificial death.

\section{TLACAHUEPAN IN THE MYTHICAL NARRATIONS}

As has been mentioned above, the Nahua historiographic framework could be described as circular, in a sense that all the significant past events represented by it were believed to be repetition of actions that had already taken place, at least once, in the primordial reality of myth. The story of Tlacahuepan's death refers to one of the most important events in Aztec mythology, namely the fall of Tollan and the shift of power from the Toltecs to the Aztecs. This significant change, which was used by the Aztecs to legitimize their domination in the Basin of Mexico, was inscribed into a much broader cosmogonic narration, according to which the Earth has been created five times. In other words, the world known to the Nahua cultural memory's audience in the sixteenth century was not the first version of reality: the universe had already been created and

64. Sahagún, Historia general, 1:146. 
destroyed four times. The story of these preceding four eras or "Suns" can be found in slightly different versions in numerous colonial sources, among them the Legend of the Suns, the Annals of Cuaubtitlan, the Codex Vaticanus A, and Historia de los mexicanos por sus pinturas. ${ }^{65}$ Although differing in detail, all these sources present the cyclical process of the subsequent creations and destructions of the world as caused by the continuous fight between two cosmic forces embodied by the gods called Tezcatlipoca and Quetzalcoatl. Each change of era was a shift of power from one of these two gods to the other.

The fourth era, which directly preceded the period of Aztec domination, was the hegemony of the city of Tollan. As Michel Graulich has observed, the story of the rise and decline of the Toltec civilization metaphorically reflected the sunrise and sunset of their principal god, the Sun, Quetzalcoatl, "The Feathered Serpent."66 Now, if the Sun of the Toltecs was Quetzalcoatl, it is not surprising that all the myths concerning the last years of his domination are presented as the time of increased activity of Quetzalcoatl's principal antagonist, Tezcatlipoca, "The Lord of the Smoking Mirror.”

In the narrations of the fall of Tollan the figure of Tezcatlipoca appears as related to several other deities, namely: Huitzilopochtli, the Mexica tutelary god of solar characteristics, who is associated with war; Xipe Totec, reported by the Historia de los mexicanos por sus pinturas as Tlatlauhqui Tezcatlipoca, "Red Tezcatlipoca"; and Tlacahuepan. ${ }^{67}$ This last character was, in the author's opinion, the basic model on which the figures of both noblemen discussed here was been based.

According to the informants of Sahagún, Quetzalcoatl fell victim to a scheme hatched by the three "sorcerers" Titlacahuan, Tlacahuepan, and Huitzilopochtli, all of whom were, at least to some extent, the avatars or messengers of Tezcatlipoca. ${ }^{68}$ To begin with, Tlacahuepan went to the marketplace of Tollan and exhibited to the Toltecs a little human figure dancing on the palm of his hand. It was a sign of the forthcoming change, as the figure in question was Huitzilopochtli, the new Sun, who would soon replace Quetzalcoatl in his ruling position. Similarly, the Tenochca nobleman Tlacahuepan, who went to die in Chalco, is presented in the cultural memory as the portent of the approaching new era, the era of Mexica domination over Chalco.

65. Bierhorst, Codex Chimalpopoca, 25-26, 139-162; Codex Vaticanus A, fols. 4v-7r; Garibay Kintana, Teogonía, $27-32$.

66. Michel Graulich, "Los reyes de Tollan," Revista Española de Antropología Americana 32 (2002): 87-114.

67. Garibay Kintana, Teogonía, 23-24; González González, Xipe Tótec, 241-390.

68. Sahagún, Historia general, 1:209-218; Olivier, Mockeries, 155. 
The convergence between the two characters goes further as the story continues. The Toltecs, attracted by the performance, swarmed around Tlacahuepan and, in consequence, many of them perished by suffocating. Likewise, both Tlacahuepan of Chalco and the one of Huexotzinco are reported to have caused the death of many of their enemies on the battlefield, where they were crowding around them and trying to reach them with their weapons. Finally, the Toltecs killed Tlacahuepan and the little Huitzilopochtli by throwing stones at them. As soon as they did it, the corpse of Tlacahuepan started to stink so much that the horrible smell killed many of the Toltecs.

Similarly, the death of Tlacahuepan in Chalco brought the revenge of Motecuhzoma and caused the death of many of its inhabitants. The Toltecs, trying to get rid of the lethal corpse, decided to haul it outside of the city, but it turned out to be impossible to move it from the place where it had fallen. ${ }^{69}$ The images from the Florentine Codex (Figure 2) and the Codex Vaticamus $A$ (Figure 3) show a group of people struggling in vain with ropes to drag Tlacahuepan, "The Human Beam," away. This scene brings to mind the preparations for the Xocotl Huetzi ritual, where the crucial point was to drag the beam. As has been mentioned before, in Nahuatl, the verb to describe this action is huepana, which is also clearly related to the name of Tlacahuepan.

What should be mentioned here as well is the presentation of the death of Tlacahuepan in Chalco in one of the images that accompany the work by Durán (Figure 4). Especially worthy of attention is the tiny detail visible in the background of the main scene. It is a human body lying on the ground, being dragged, like a beam, by another person. This human body is linked to the head of the main protagonist, following the convention used in the Nahua codices for proper name glyphs. In other words, the graphic way of representing Tlacahuepan is similar in both cases, clearly connecting his name with his role.

Another aspect of the role played by Tlacahuepan in both myths and cultural memory narrations is his identity as a foreigner and, in particular, as a Huastec. According to the chroniclers, both these warriors, whose deaths in Huexotzinco and Chalco were then commemorated with the picturesque narrations of the Nahua cultural memory, belonged to the Tenochca aristocracy. Thus, the fact of describing Tlacahuepan as a Huastec in the songs must have had purely symbolic and metaphorical meanings. Some of them have already been commented on in the section dedicated to the analysis of the songs. Yet, there are also mythical bases for this comparison.

69. Sahagún, Historia general, 1:214-215. 
FIGURE 2

Toltecs Dragging the Corpse of Tlacahuepan

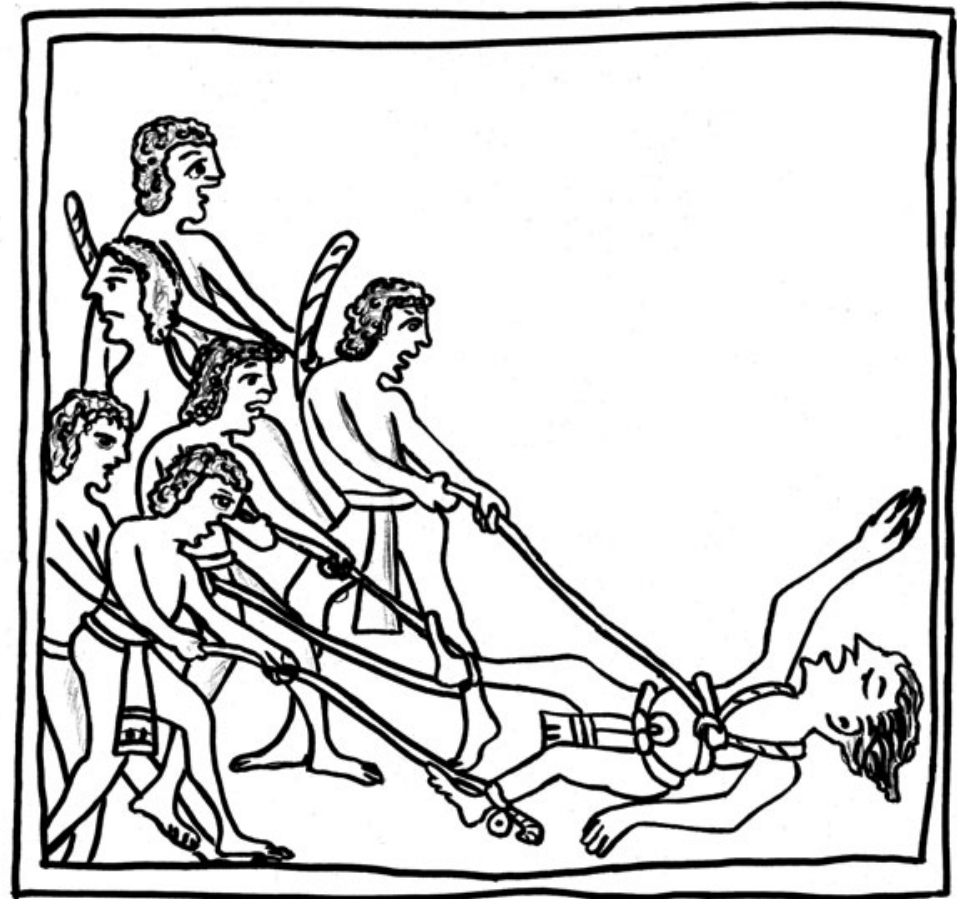

Source: Bernardino de Sahagún, (1950-1982), , Florentine Codex, A.J.O. Anderson and Ch. E. Dibble (eds.), Santa Fe, The School of American Research-University of Utah; bk. 3: 11, redrawn by Katarzyna Szoblik

The role of the Huastecs in the myths of the fall of Tollan constitutes them as the archetypal sacrificial victims. As mentioned above, among the omens predicting the fall of Tollan, there was the introduction of various feasts of the ritual calendar called xiuhpohualli. According to the Annals of Cuaubtitlan, the Huastec captives were used as victims in the initiation of the feast of Izcalli:

8 Rabbit [1058] In that year there were many evil omens in Tollan. Well, it was the same year that sorcerers arrived, the so-called ixcuinanme, the female devils. And according to the stories of the old people, which tell how they came, they issued forth from Cuextlan. And at so-called Cuextecatlichocayan [Place Where the Cuexteca Weep] they spoke to the captives they had taken in Cuextlan and made them a promise, saying, "We are going to Tollan now. You will go with us, and when we get there, we will use you to make a celebration, for there has never been an arrow shoot. And we are the ones who are going to start it by 
FIGURE 3

Toltecs Dragging the Corpse of Tlacahuepan

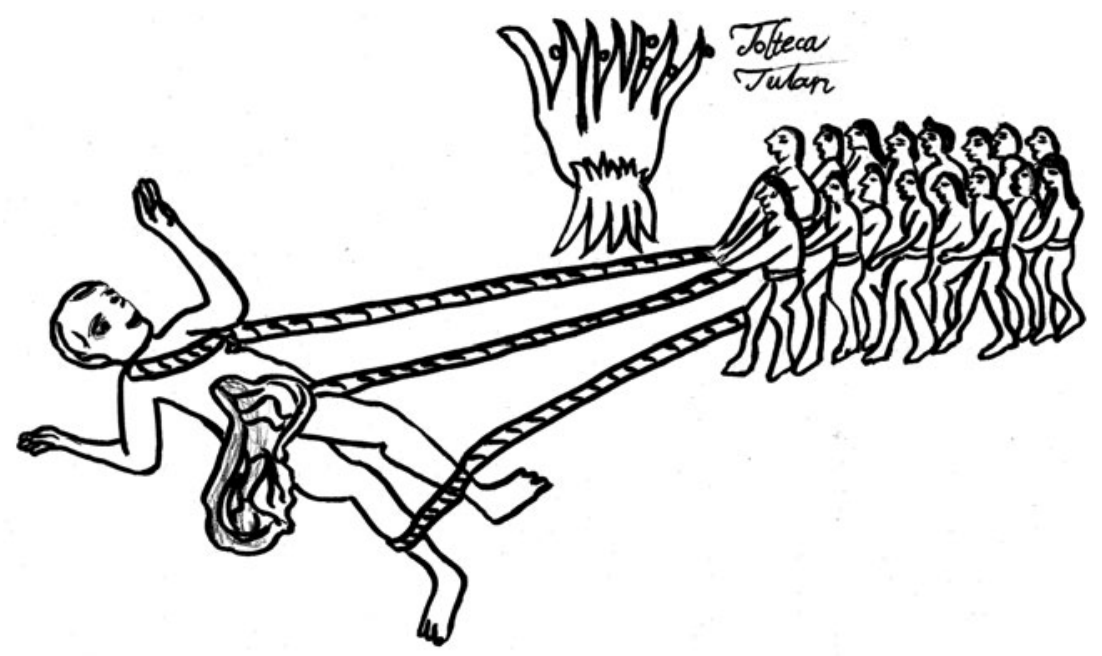

Source: Códice Vaticano A (1996) F. Anders, M. Jansen and L. Reyes García (eds.), Graz-Mexico, Akademische Druck- u. Verlagsanstalt -Fondo de Cultura Económica, f. 8v, redrawn by Katarzyna Szoblik

shooting you." When the captives heard this, they wept, they grieved. Then the arrow shoot began, and in this way a feast used to be celebrated in honor of the ixcuinanme at the time of the so-called Izcalli. ${ }^{70}$

The Huastecs are presented here as sacrificial victims, whose death is intended to support the plans of Tezcatlipoca. In the same way, the sacrificial death of Tlacahuepan-the Huastec, as presented in Nahua cultural memory-was calculated into the plans of Motecuhzoma to bring destruction to Chalco. Finally, it should be mentioned that the Huastec, or Tobueyo, was also one of the forms taken by Titlacahuan to mislead the Toltecs. According to Sahagún's informants, the huge naked member of the anonymous foreigner who came one day to sell green chilis on the marketplace in Tollan provoked such a passion in the Huemac's daughter, that the ruler had no other possibility than to propose her in matrimony to the Huastec. ${ }^{71}$ In this way, the rule over Tollan

70. 8 tochtli. Ipan in in xihuitl in cenca miec tetzahuitl mochiuh timanca Tollan. Aub no iquac ipan in in xihuitl oncan acico in tlatlacatecollo inmitoaya Ixcuinanme cihua Diablome; aub inyubca in tlatol huehuetque conitoa inic huallaque Cuextlampa in quizaco. Auh in ompa mitoa Cuextecatl ichocayan, oncan quin nonotzque in malhuan qui macique Cuextlan quin polyubtlamachtique in quimilhuique ca ye tibui in Tollan, amocatlaltechtacizque amocatilhuichibuazque, ca aya ic tlacacalibua ø tehuantin ticpehualtitihua tamech miminazque in oquicacque in malhuan, niman ic chocaque tlaocoxque oncan tzintic y in tlacacaliliztli, inic ilhuichibuililoya Ixcuinanme, iniquac mitoaya Itzcalli. Bierhorst, Codex Chimalpopoca, 39-40.

71. Sahagún, Florentine Codex, 3:17-18 
FIGURE 4

The Death of Tlacahuepan According to Diego Durán

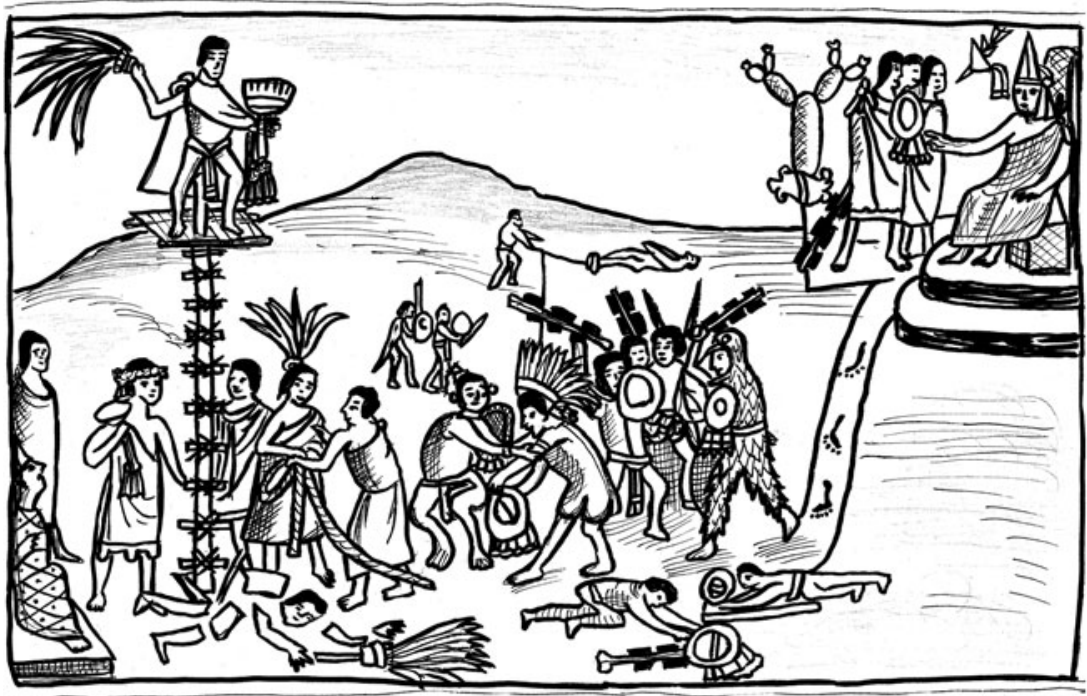

Source: Diego Durán (1579) Historia de las Indias de Nueva España e Islas de la Tierra Firme, digitalized manuscript accessible on: http://bdh-rd.bne.es/viewer.vm?id=0000169486\&page =1, f. 52r, redrawn by Katarzyna Szoblik

was given to the foreigner-who could be described as the Huastec Lord - and all the attempts undertaken by Huemac to get rid of the unwanted son-in-law by sending him to death in an arranged war campaign resulted in futility.

\section{CONCLUSIONS}

Both narrations analyzed in this article, with their similar narrative structures, evoke the heroes and events of primordial times as archetypes for the historical characters' actions, and thus perfectly reflect the cyclical character of the Nahua understanding of time and history. Their basic mythical point of reference is the fall of Tollan, which, according to different myths, had been prophesied by a series of omens, among which were the initiation of the flowery war, the introduction of human sacrifices and other rituals of the feasts of xiuhpohualli, and the death of the new Sun's messenger, called Tlacahuepan.

In the political reality of fifteenth-century Central Mexico, this new "Sun" coming to reign over the local communities was the domination of the Aztecs, represented 
by the solar characteristics attributed to the supreme ruler of Tenochtitlan. That is why Tlacahuepan, delegated by Motecuhzoma to bring war to the problematic city-states, repeats the actions of his mythical namesake, intentionally arranging his death in such a manner that it can be classified as a sacrifice. The songs call him a Huastec, the foreigner from the land of dawn, a title which, among other metaphorical meanings, obviously makes reference to his role as Sun's messenger and a model sacrificial victim.

There is, however, one substantial difference between the two tales. In Chalco, Tlacahuepan manages to fully repeat the role of his mythical archetype by bringing destruction to the enemies and "buying" with his death the victory of the Mexica. In Huexotzinco however, despite his sacrifice, the Mexica are forced to retreat. What is more, they do not dare to go back and challenge the Huexotzinca again. Instead, they organize a campaign against some weaker communities, whose members do not even come to face them on the battlefield, but simply abandon the cities in fear.

The explanation of this difference can be found in the analysis of the works supposedly based on the same lost manuscript of so called Chronicle X. As suggested by Sylvie Peperstraete, the sources in question, already written down in the colonial reality and by authors familiar with the history of the recent Spanish conquest, repeat the same narrative model with which the myths presented the history of Tollan. They illustrate the development and decline of Tenochtitlan's hegemony as metaphorically resembling the way of the Sun in the firmament. According to Peperstraete, the concordance of names between Motecuhzoma Ilhuicamina and Motecuhzoma Xocoyotzin, as well as the numerous parallels between the stories of their rule, are by no means accidental.

The first ruler, registered as the middle one on the list of the Tenochca tlatoque, personifies in fact the Sun at noon, when it is the most powerful. For this reason, the period of his rule is also the time of the greatest splendor of Tenochtitlan, which seems literally invincible. Motecuhzoma Xocoyotzin, on the other hand, takes power on the eve of the Spanish conquest, and for this reason, he personifies the sun at sunset, which is old, weak, heavy, and heading toward its destruction. ${ }^{72}$ That is why, in the author's opinion, the ritual death of Tlacahuepan was not able to change the result of the conflict with Huexotzinco. The power delegated by the tlatoani to his messenger proved not to be strong enough to repeat the successes from Tollan and Chalco. This failure revealed the forthcoming end of Aztec domination and was one of the 
portents of the approaching shift of power that would take place with the arrival of the Spaniards. In this way another cycle of time in the Nahua historiography was concluded, and the new era began.

University of Warsaw

KATARZYNA SZOBLIK

Warsaw, Poland

kszoblik@uw.edu.pl 